\title{
Using oligochaeta assemblages as an indicator of environmental changes
}

\author{
Behrend, RDL. ${ }^{a *}$, Takeda, AM. ${ }^{b}$, Gomes, LC. ${ }^{b}$ and Fernandes, SEP. ${ }^{a}$ \\ ${ }^{a}$ Curso de Pós-graduação em Ecologia de Ambientes Aquáticos Continentais, Departamento de Biologia, \\ Universidade Estadual de Maringá - UEM, Colombo, 5790, CEP 87020-900, Maringá, PR, Brazil

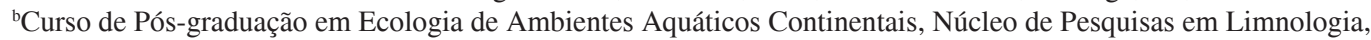 \\ Ictiologia e Aquicultura - NUPÈLIA, Departamento de Biologia, Universidade Estadual de Maringá - UEM, Colombo, \\ 5790, CEP 87020-900, Maringá, PR, Brazil \\ *e-mail: romulobehrend@yahoo.com.br
}

Received November 25, 2011 - Accepted March 14, 2012 - Distributed November 30, 2012

(With 3 figures)

\begin{abstract}
We designed a field survey (the entire river length; not dammed: First and Second plateaus; dammed: Third Plateau) to test the hypothesis that the cascade of reservoirs promoted a reduction in species richness and changed the composition of Oligochaeta assemblage along the Iguaçu River. Changes in environmental variables and in richness and composition of Oligochaeta were summarized by Canonic Correspondence Analysis. Along the Iguaçu River, conductivity, and altitude decreased, whereas temperature increased. Oligochaeta composition showed a significant spatial variation, with higher abundances of the family Tubificidae and the genus Dero (Naididae) occurring in the First Plateau. In the Second and Third plateaus, few species were dominant, with increases in the presence of species of Naididae below dams. We found a clear decrease in species richness along the Iguaçu River. Moreover, we found that Oligochaeta assemblage was influenced by some environmental variables such as altitude, conductivity, substrate type and temperature, and by anthropogenic activities (human occupation and damming). The results supported the use of Oligochaeta as surrogate taxa to predict environmental changes along impacted (dammed and eutrophic) rivers. The validity of this was indicated by the strong and significant gradient registered, from the headwater to mouth of the Iguaçu River.
\end{abstract}

Keywords: surrogate taxa, reservoir cascade, geomorphologic gradient, human occupation, Iguaçu River.

\section{Usando assembléias de Oligochaeta como um indicador de mudanças ambientais}

\section{Resumo}

Foi delineada uma pesquisa de campo (toda extensão do rio; não barrado: Primeiro e Segundo planaltos; barrado: Terceiro planalto) para testar a hipótese de que a cascata de reservatórios promove redução na riqueza de espécies e muda a composição da assembléia de Oligochaeta ao longo do Rio Iguaçu. Mudanças nas variáveis ambientais e na riqueza e composição de Oligochaeta foram sumarizadas por Análise de Correspondência Canônica. Ao longo do Rio Iguaçu, a condutividade e a altitude diminuíram, enquanto a temperatura aumentou. A composição de Oligochaeta mostrou variação espacial significativa, com maiores abundâncias da família Tubificidae e do gênero Dero (Naididae) ocorrendo no Primeiro planalto. No Segundo e Terceiro planaltos, poucas espécies foram dominantes, com aumento na presença de espécies de Naididae abaixo de barragens. Foi encontrada uma clara diminuição na riqueza de espécies ao longo do Rio Iguaçu. Além disso, observou-se que a assembléia de Oligochaeta foi influenciada por algumas variáveis ambientais, como altitude, condutividade, tipo de substrato e temperatura, e por atividades antropogênicas (ocupação humana e barramento). Os resultados deste estudo suportam o uso de Oligochaeta como táxon substituto para predizer mudanças ambientais ao longo de rios impactados (barrados e eutróficos). A validade desse estudo foi indicada pelo forte e significativo gradiente, registrado da cabeceira à foz do Rio Iguaçu.

Palavras-chave: taxon substituto, cascata de reservatório, gradiente geomorfológico, ocupação humana, Rio Iguaçu.

\section{Introduction}

Identifying the distribution patterns of species is an important step in determining what processes control the structure of riverine communities (Brosse et al., 2003). Species respond distinctively along environmental gradients at various spatial scales (Cottenie 2005; Heino et al., 2007), and invertebrate communities in lotic systems may be structured along resource gradients from the headwaters to the mouths (Vannote et al., 1980). This gradient may 
be disrupted by the construction of dams, especially downstream, as predicted by the serial discontinuity concept (Ward and Stanford, 1983).

The regulation of river flow produces many negative impacts, because it modifies intensity, duration and seasonality of floods, reduces loads of nutrients in seasonally flooded areas and creates unstable thermal and hydrodynamic conditions in segments immediately below dams (Petts, 1984; Ward and Stanford, 1995). Moreover, it causes loss of habitats and diversity due to geomorphologic adjustment of the river system toward a new equilibrium condition (Petts and Greenwood, 1985). These impacts are increased when dams are built in series (Barbosa et al., 1999; Callisto et al. 2005).

Cascades of reservoirs results in the formation of a complex pattern of interactions that can be perceived along the longitudinal axis of impacted rivers, resulting in physical, chemical and biological alterations. In a cascade of reservoirs, both alterations in water quality and in composition and distribution of biota are results of modifications in lateral, vertical and longitudinal dimensions, as described in the Cascading Reservoir Continuity Concept (Barbosa et al., 1999).

Benthic macroinvertebrates are one of the groups affected by the cascade of reservoirs (Callisto et al., 2005; Jorcin and Nogueira, 2008). The flow regulation and stratification patterns developed in reservoirs frequently impact the biota downstream in four ways (Cortes et al. 2002): i) alteration of physical and chemical characteristics associated with the release of water and sediment derived from the hypolimnion, that affect life history and density of macroinvertebrates (Cortes et al. 2002); ii) alteration of available food resources to aquatic biota, specially through changes in the particulate organic matter (McAllister et al. 2001); iii) creation of unstable environment due to daily changes in water level, increasing invertebrate drift (Hansen and Closs 2007); and iv) reduction of water released downstream, which modify abundance and diversity of benthic fauna (Bunn and Arthington, 2002). These effects have been demonstrated in several regulated rivers, where alterations in discharge have caused changes in the structure of the aquatic community (Pardo et al., 1998; Rosin et al., 2009).

Within the aquatic assemblages, Oligochaeta is one of the groups strongly affected by dams (Suriani et al., 2007). Oligochaeta species richness is directly related to food availability (Collado and Schmelz, 2001) and quality (Pasteris et al., 1994; Collado and Schmelz, 2001), substrate type (Verdonschot, 2001; Bletter et al., 2008), oxygen availability (Collado et al., 1999; Nijboer et al., 2004), and biological interactions (Darrigran et al., 1998). In addition, this group presents a low dispersion, and most of them are considered indicators of specific habitats (Verdonschot, 2001), of hydro-morphological character (Verdonschot, 2001), and of trophic state (Suriani et al., 2007). Based on these characteristics, we used Oligochaeta as surrogate taxa to identify environmental changes in aquatic ecosystems altered by dams, such as the Iguaçu River, which has five large dams in its $1,000 \mathrm{~km}$ course. In general, reservoirs negatively impact species richness of macroinvertebrates, including Oligochaeta (Suriani et al., 2007). Thus, we designed a field survey (the entire river length) to test the hypothesis that the cascade of reservoirs promoted reduction in species richness and changed the composition of Oligochaeta assemblage along the Iguaçu River.

\section{Material and Methods}

\subsection{Study area}

The Iguaçu River basin has a drainage area of $70,800 \mathrm{~km}^{2}$, and cuts the Paraná State from east to west, travelling more than $1,000 \mathrm{~km}$, from its headwater to its mouth. The Iguaçu River runs along the three Paranaenses plateaus, with a difference in altitude over 900 m (Maack, 2002) (Figure 1). Lower Precambrian rocks cover the First Plateau; Paleozoic sedimentary rocks cover the Second Plateau; and Mesozoic volcanic rocks cover the Third Plateau (Merenda, 2004).

Along the longitudinal axis of the Iguaçu River, human occupation also changes along the Iguaçu River. The First Plateau is located in the Metropolitan area of Curitiba (2.5 million inhabitants). There are several industries in this area, including mining. In this stretch, the Iguaçu River receives raw sewage inputs from sanitary sewers as well as from households along the tributaries (Sodré and Grassi, 2006). In the Second and Third plateaus, the main economic activities are agriculture and timber (Julio Junior et al., 1997).

Due to the high slope of the Iguaçu River, a series of five large dams (Foz do Areia - 13.850 ha, Segredo - 8.250 ha, Salto Santiago - 21.360 ha, Salto Osório - 5.990 ha and Salto Caxias - 14.090 ha) was constructed with the primary purpose to produce electricity. However, the portions of the river that run on the First and Second plateaus are still not dammed and are located above the first reservoir of the cascade.

\subsection{Sampling}

Along the Iguaçu River, 480 bottom samples were collected (360 for biological analysis and 120 for granulometric analysis). Samplings were carried out from January $29^{\text {th }}$ to February $12^{\text {th }}, 2006$ in 11 lotic stretches of the Iguaçu River following a priori sampling design, developed to cover the main features of the river (First Plateau = Balsa Nova: $86 \mathrm{~km}$ of distance from headwater; Second Plateau = Água Azul: 231 km, São Mateus: 280 km and União da Vitória: $430 \mathrm{~km}$; Third Plateau = Faxinal do Céu: 534 km, Reserva do Iguaçu: 675 km, Sulina: 766 km, Cruzeiro do Iguaçu: 846 km, Capitão Leônidas Marques: 936 km, Capanema: 1036 km and Foz do Iguaçu: $1166 \mathrm{~km}$ ). In each stretch, five sampling stations were selected at random, except in Capanema, where ten 

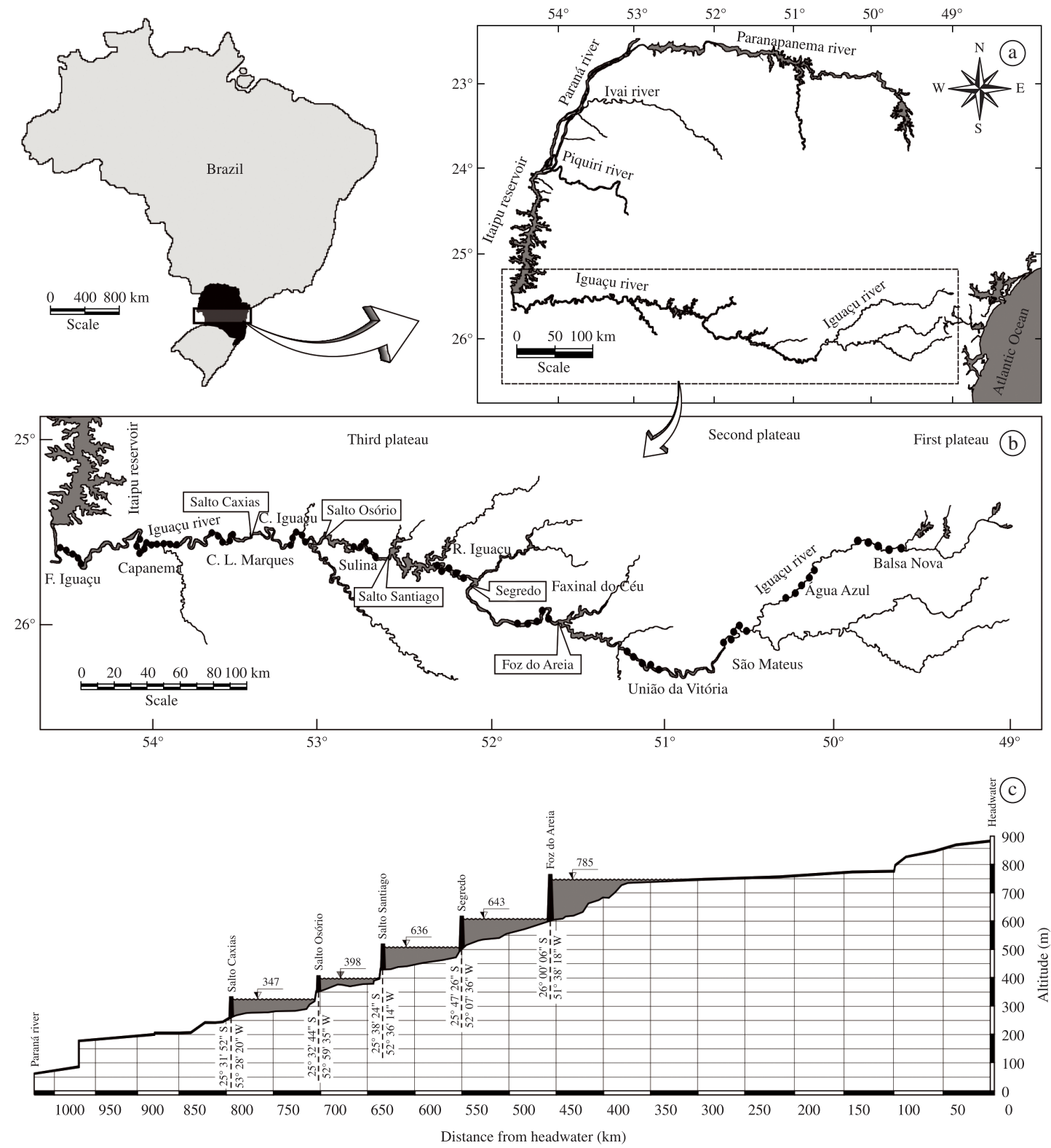

Figure 1. (ab) Location of the Iguaçu River basin showing the sampled stretches (dots in panel b), and (c) the cascade of reservoirs along its course - numbers on the reservoirs correspond to their altitudes. Modified from Julio Junior et al. (1997).

stations (all in the right margin; left margin belongs to Argentina) were established. At each station, two sites were selected (right and left margins), and at each site four samples were taken (three for biological analysis and one to determine texture and organic matter content) using a Petersen grab $\left(0.0345 \mathrm{~m}^{2}\right)$.

Every sample was stored in a gallon, fixed with $4 \%$ formaldehyde and later washed in 2.0, 1.0 and $0.2 \mathrm{~mm}$ sequential sieves. The sediment retained in the last sieve was fixed in 70\% alcohol. Oligochaeta species were identified according to the key of Brinkhurst and Marchese (1991) using an optic-microscope.

\subsection{Environmental variables}

We measured 16 variables that may influence Oligochaeta distribution in every sampling station: water velocity $\left(\mathrm{m} . \mathrm{s}^{-1}\right.$; General Oceanics Model n ${ }^{\circ} 2035$ MKIV); conductivity $\left(\mu \mathrm{S} . \mathrm{cm}^{-1}\right.$; Digimed DM-3P); total suspended material (mg.L $\left.\mathrm{L}^{-1}\right)$; total phosphorus (mg. $\left.\mathrm{L}^{-1}\right)$; total nitrogen $\left(\mathrm{mg} . \mathrm{L}^{-1}\right)$; water temperature $\left({ }^{\circ} \mathrm{C}\right)$ and dissolved oxygen concentration (mg.L ${ }^{-1}$; YSI-550A); pH (Digimed DM 2P); turbidity (NTU; Quimis - Q-179); depth (m; Ecosonda Hondex (PS-7); altitude (m; GPS Garmin - Etrex); and pebble, gravel, sand, mud and organic matter (all in percentage). Mean values ( \pm standard deviation) of these variables are shown in Table 1. 


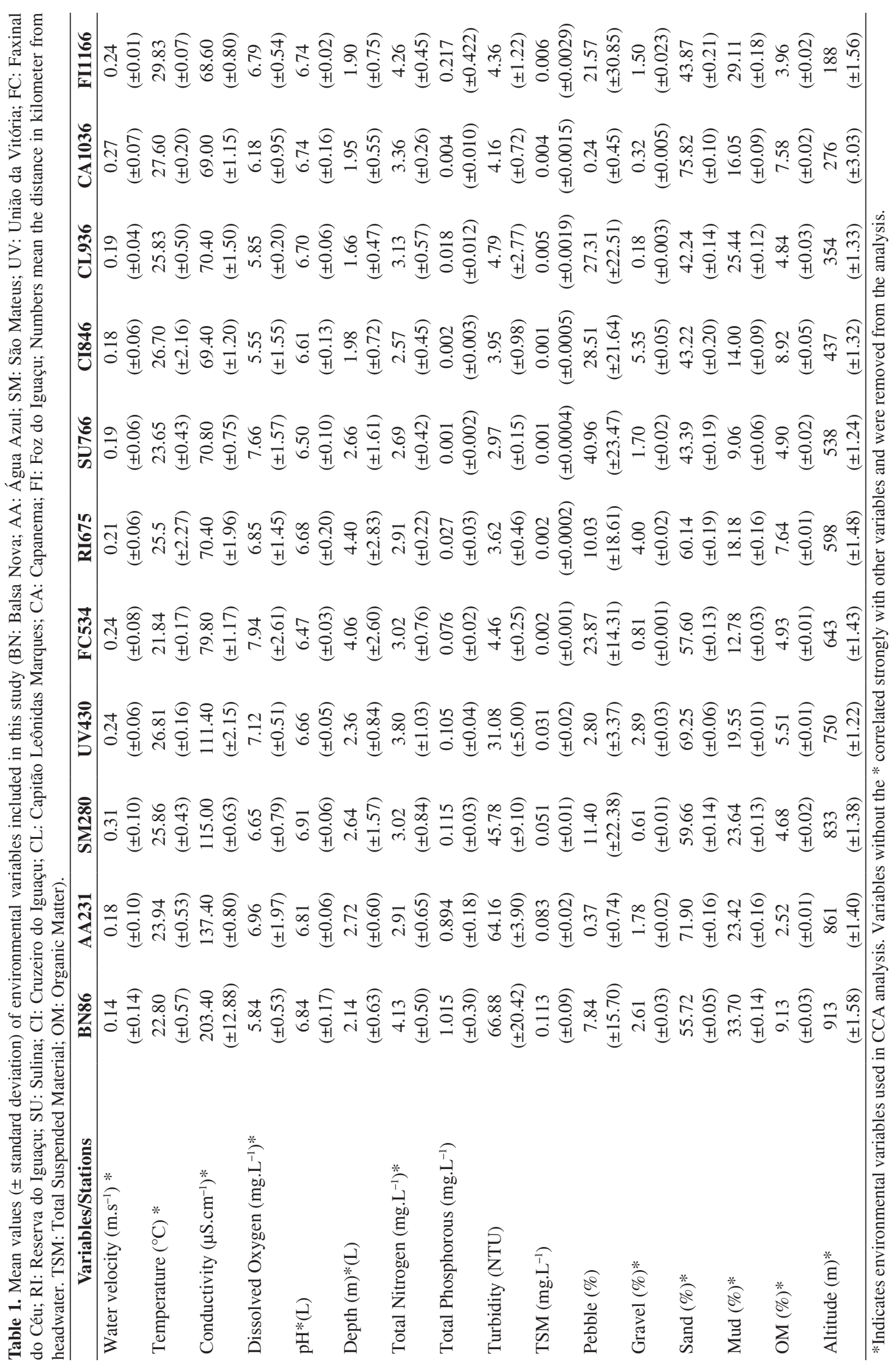




\subsection{Data analysis}

For analysis and following the purposes of the paper, sampling stations were converted to distance from the headwater of the Iguaçu River used in the sampling design, but controlling the position of the sites along the cascade of reservoirs ("not dammed": First and Second plateaus; dammed Third Plateau). Thus, with this categorization, we could better evaluate the effects of the dams on the Oligochaeta assemblage.

\subsection{Longitudinal variations in species richness}

Species richness (number of species) was determined for every sample. One-way ANOVA (Random factor: distance from the river headwater) was used to determine differences between the averages of species richness. Oligochaeta richness in the sampled stretches was additionally compared with rarefaction curves to eliminate the effect of abundance (Gotelli and Colwell, 2001).

\subsection{Gradient in the Oligochaeta assemblage and relationships with environmental variables}

The Canonical Correspondence Analysis (CCA) was used to determine possible longitudinal gradients and to select environmental variables that most influenced the composition of Oligochaeta assemblage along the Iguaçu River. We opted for this analysis due to the biology of the studied group, whose species does not move intensely along the bottom, promptly responding to environmental variables. To avoid multicollinearity in CCA, we calculated pairwise correlations among environmental variables. When value of the correlation was higher than $0.7(r>0.7)$, we removed a certain variable and repeated the correlation analysis to check if it still had correlation among variables. Pebbles (\%), total phosphorous, turbidity and total suspended material were significant, but greatly redundant with other environmental variables and were excluded from the analysis. Species abundances were $\log (\mathrm{x}+1)$ transformed and rare species were down-weighted because they have a relatively large influence in the results of ordinations and are also more likely than common species to be inadequately sampled.

To test the significance of the between-group differences summarized by CCA scores, we used a multi-response permutation procedure (MRPP), which is a nonparametric method for testing multivariate differences among predefined groups (in our case, distance from headwater; $\mathrm{km}$ ). This analysis was performed using a resemblance matrix based on the Bray-Curtis coefficient.

To better interpret the ordination resulted from the CCA, we applied the method of the Indicator Value (IndVal) (Dufrene and Legendre, 1997). This analysis helped us to determine the species that most discriminated each sampled stretch (in the case, distance from the headwater) and these results were compared with the CCA ordination, overlaid by the species used in the analysis. Analyses were based on raw abundance data.

CCA, MRPP and IndVal were computed using the software PC-Ord ${ }^{\circledR}$ 5.0. Rarefation curves were performed using the program PRIMER-E 6 + PERMANOVA. Analysis of variance (ANOVA) was performed using the software Statistica $7.0^{\mathrm{TM}}$.

\section{Results}

\subsection{Oligochaeta survey}

A total of 12,780 individuals of Oligochaeta were recorded during the study, belonging to at least 25 species. The families registered were Enchytraeidae (species not identified), Opistocystidae (one species), Alluroididae (one species), Tubificidae (five species), and Naididae (18 species).

\subsection{Longitudinal variations in species richness}

Species richness differed significantly between stretches (distance from the headwater) of the Iguaçu River (ANOVA; $\mathrm{F}=30.09 ; \mathrm{p}<0.01$ ) (Figure $2 \mathrm{a})$. The highest mean value (a)

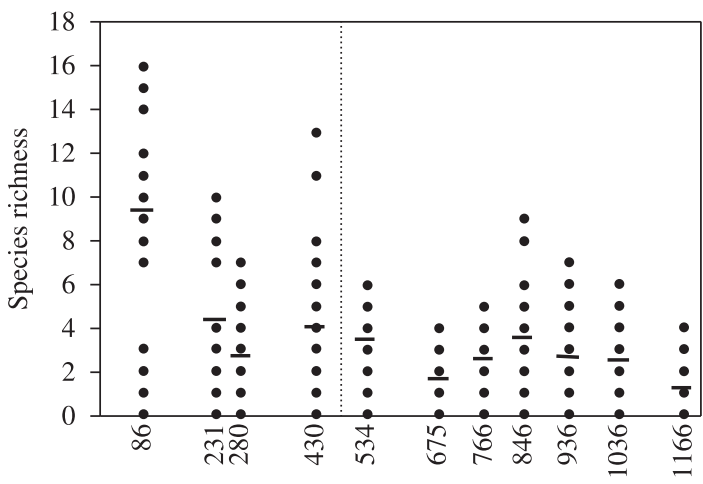

Distance from headwater $(\mathrm{km})$ (b)

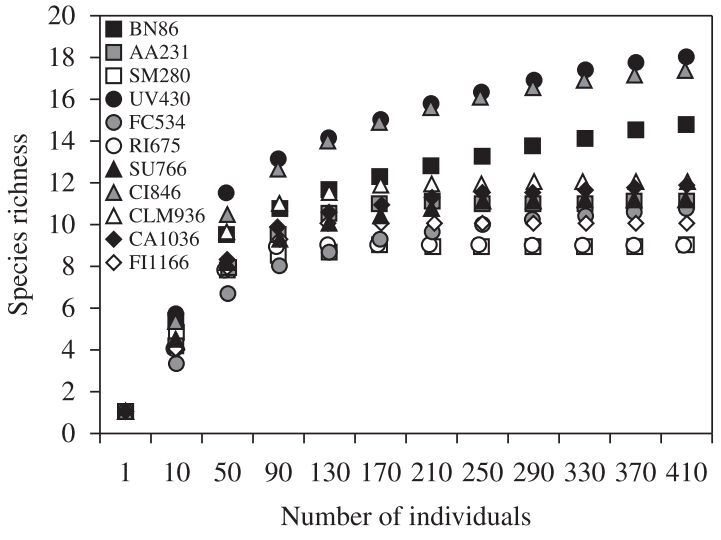

Figure 2. (a) Scatterplot of species richness (S) of Oligochaeta assemblage in the sampled stretches of the Iguaçu River, here represented as distance from the headwater (horizontal short lines are the averages for each stretch). (b) Species rarefaction curves, corrected to Oligochaeta abundances in the sampled stretches of the Iguaçu River. BN: Balsa Nova; AA: Água Azul; SM: São Mateus; UV: União da Vitória; FC: Faxinal do Céu; RI: Reserva do Iguaçu; SU: Sulina; CI: Cruzeiro do Iguaçu; CL: Capitão Leônidas Marques; CA: Capanema; FI: Foz do Iguaçu - Numbers are distances from headwater in kilometers. 
of species richness was registered in the upper stretch (Balsa Nova; $86 \mathrm{~km}$ from the river headwater; First Plateau, not dammed). Higher mean values were also registered from km 231 to 430 (Second Plateau; not dammed). However, when the distance from the headwater presented reservoirs (534 km and higher), the mean species richness were lower, especially near the Paraná River (1166 km) (Figure 2a). The rarefaction curves showed similar trend when compared to the mean value of species richness, with only change in position of the sampling stations. Then, to this method, species richness was greater in União da Vitória (UV430), followed by Cruzeiro do Iguaçu (CI846) and Balsa Nova (BS86) (Figure 2b), which are the ones with higher mean species richness (Figure 2a).

\subsection{Longitudinal gradient in the Oligochaeta assemblage and relationships with environmental variables}

Canonical Correspondence Analysis (CCA) determined the spatial gradients and identified the influence of the selected environmental variables in the composition of Oligochaeta assemblage (Monte Carlo test - species-environment correlations; $\mathrm{p}<0.01$ ) (Figure 3). Two axes were retained for interpretation (cumulative variance $=27 \%$ ). Scores for axis $1(19.9 \%$ of the variance, eigenvalue $=0.32)$ described an East to West gradient, with stations in the upper part (East; near the headwater: First and Second plateaus) of the Iguaçu River, registering higher values of altitude, conductivity, and lower values of temperature, but high abundances of species of the family Tubificidae (Limnodrilus hoffmeisteri, Branchiura sowerbyi, Bothrioneurum americanum, Paranadrilus descolei, and Aulodrilus pigueti) and the genus Dero (Dero (Dero) multibranchiata, D. (D.) digitata, D. (D.) sawayai, Dero (Aulophorus) costatus and D. (A.) borellii) (Table 2). In the stretches far from the headwater (West; dammed stretches; Third Plateau), the values of these environmental variables gradually decreased, but the temperature increased. The highest abundances of Naididae species were recorded in these stretches. The geological and climatic gradient, along with the population contingent in the First Plateau and the reservoir cascade in the Third Plateau, appeared to be the main factors that determined the distribution of Oligochaeta in the Iguaçu River. Scores for axis $2(7.1 \%$ variance, eigenvalue $=0.11)$ separated, to a lesser extent, upper stretches (First and Second plateaus; not dammed) from the lower stretches (Third Plateau; dammed), far from the river headwater. These gradients, identified in the CCA, were confirmed by the Multi-Response Permutation Procedure (MRPP; $\mathrm{A}=0.14 ; \mathrm{p}<0.05)$.

The stretches of the Iguaçu River were characterized by 21 species (significant INDVAL; p < 0.05) (Table 2) that presented preference for some locations. Fifteen species were characteristic of the stretches closer to the headwater of the river (First and Second plateaus; not dammed stretches), and six species were characteristic of the stretches located in the cascade of reservoirs (Third Plateau, dammed stretches). The large number of species with significant indicator values in the upper stretches and the significant MRPP $(\mathrm{A}=0.14 ; \mathrm{p}<0.05)$, indicated that there were significant differences in the composition of Oligochaeta assemblage along the stretches. Most important variables explaining these differences were altitude, conductivity and type of substrate (mud and sand).

\section{Discussion}

The number of Oligochaeta species registered along the Iguaçu River was greater than the number found in other rivers of the upper Paraná River basin - Baía (22) and Ivinhema (22) rivers (Behrend et al., 2009), Ivaí (20) and Piquiri (12) rivers (Fernandes et al. in prep.) and the upper Paraguay River (22) (Marchese et al., 2005). The richness of Oligochaeta species recorded in this river is related to the environmental heterogeneity (several falls, rapids, pools and backwaters), since it cuts the three Paranaense plateaus formed by rocks from different geological times, besides altitude and anthropogenic activities, which were the main variables explaining the patterns found. Thus, the geomorphology of the Iguaçu River basin could have created different micro-habitats in the bottom (muddy, sandy or rocky), and human pollution may have increased the input of food resources, leading to optimal conditions for Oligochaeta. The increase of invertebrates at a local scale (in rivers) is directly proportional to the diversity of conditions of a given locality (Vinson and Hawkins, 1998).

There is a tendency to consider that species richness of macroinvertebrates increases with the basin area or with the length of the river, because downstream areas can act as wells for individuals brought from the headwater area upstream (Jacobsen et al., 1997). However, we did not verify this, because the First Plateau (near the headwater; not dammed), presented the highest species richness, probably due to the sewage (input of nutrients) from large cities. These inputs may have favored Oligochaeta in the First Plateau because these organisms are commonly related to environments with low water quality (Diaconu and Risnoveanu, 1993). Nevertheless, the historic importance of this Plateau should also be considered, because it is the oldest and many species may have been settled there for some time. Thienemann (1954) emphasized that the longer a locality has been in the same situation, the richer and the more stable is its community, supporting our findings.

The lowest species richness was registered in stretches in the Third Plateau, located along the cascade of reservoirs. The rapid numerical increase of dams has caused widespread loss of freshwater habitats, especially waterfalls, riparian floodplains and wetlands. Therefore, the construction of dams can cause profound negative effects on aquatic biodiversity because the natural seasonal patterns to which the fauna has adaptations is altered, and normal seasonal migration paths (drifts) are blocked (Rosenberg et al. 2000). Callisto et al. (2005) observed that reservoirs in cascades cause significant changes in the original continuum of a river, altering the thermal heterogeneity, the connectivity, the fine and the coarse particulate organic matter rates. These changes can lead to significance effects on the communities 
of invertebrates, causing loss of aquatic diversity. These factors, associated with aggregate distribution and the low mobility of Oligochaeta species appears to be the reasons why stretches in the Third Plateau recorded the lowest values of species richness.
Recent studies have shown, for example, that species richness is not only controlled by local factors but also by regional-scale processes such as dispersal and historical events (Shurin et al., 2000; Heino et al., 2003). Dispersal is a major regional process that may constrain local

(a)

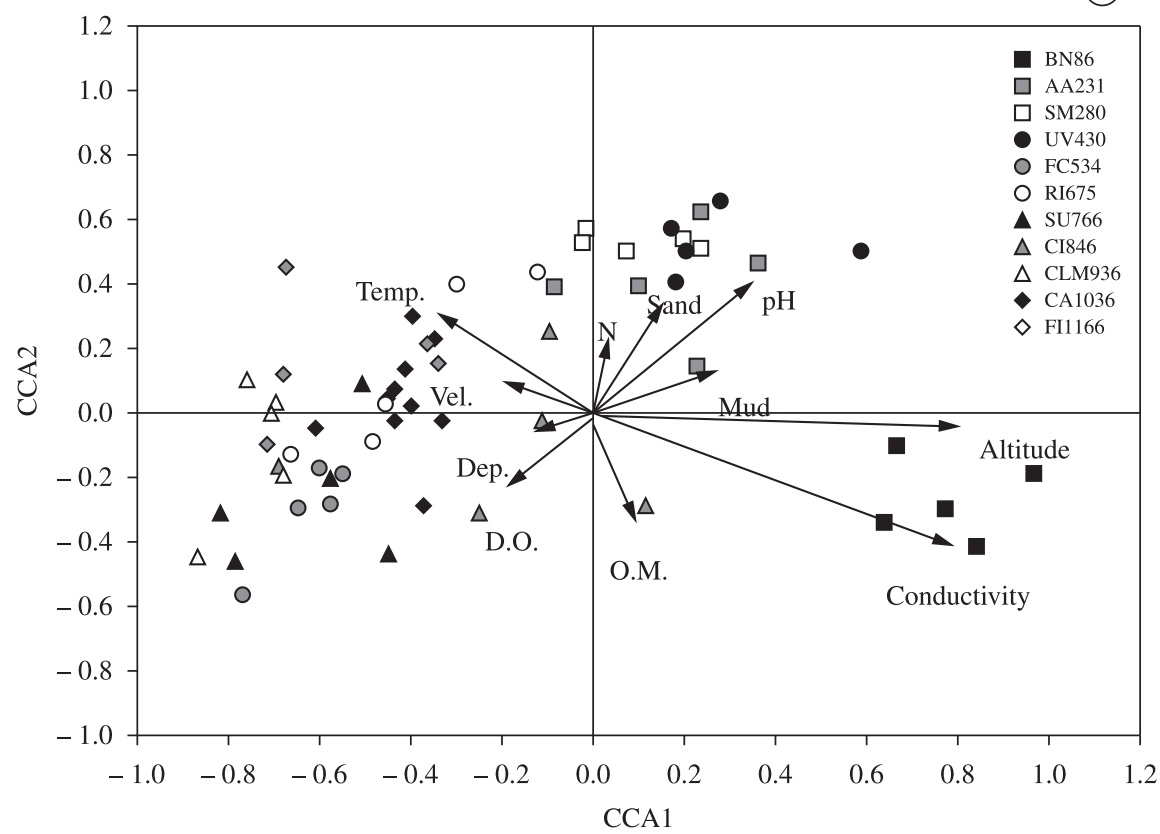

(b)

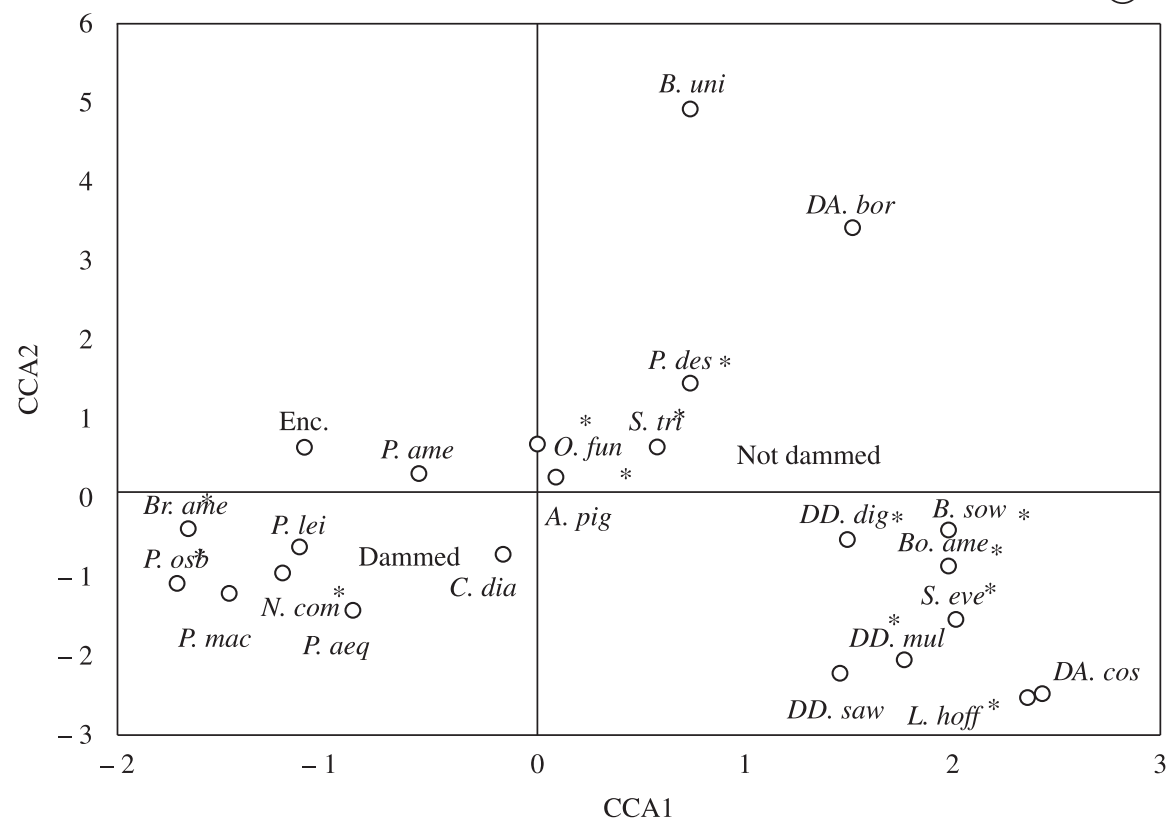

Figure 3. Ordination of sampled stretches (a) and of Oligochaeta assemblage (b) with environmental variables, using Canonical Correspondence Analysis (CCA). Species with asterisks were indicators of the not dammed or dammed stretches, regarding the Indicator Value (IndVal; Table 2). Temp. Temperature; Vel. Water Velocity; Dep. Depth; D.O. Dissolved Oxygen; N. Total Nitrogen; O.M. Organic Matter; BN: Balsa Nova; AA: Água Azul; SM: São Mateus; UV: União da Vitória; FC: Faxinal do Céu; RI: Reserva do Iguaçu; SU: Sulina; CI: Cruzeiro do Iguaçu; CL: Capitão Leônidas Marques; CA: Capanema; FI: Foz do Iguaçu - Numbers are distances from headwater in kilometers. 
Behrend, RDL. et al.

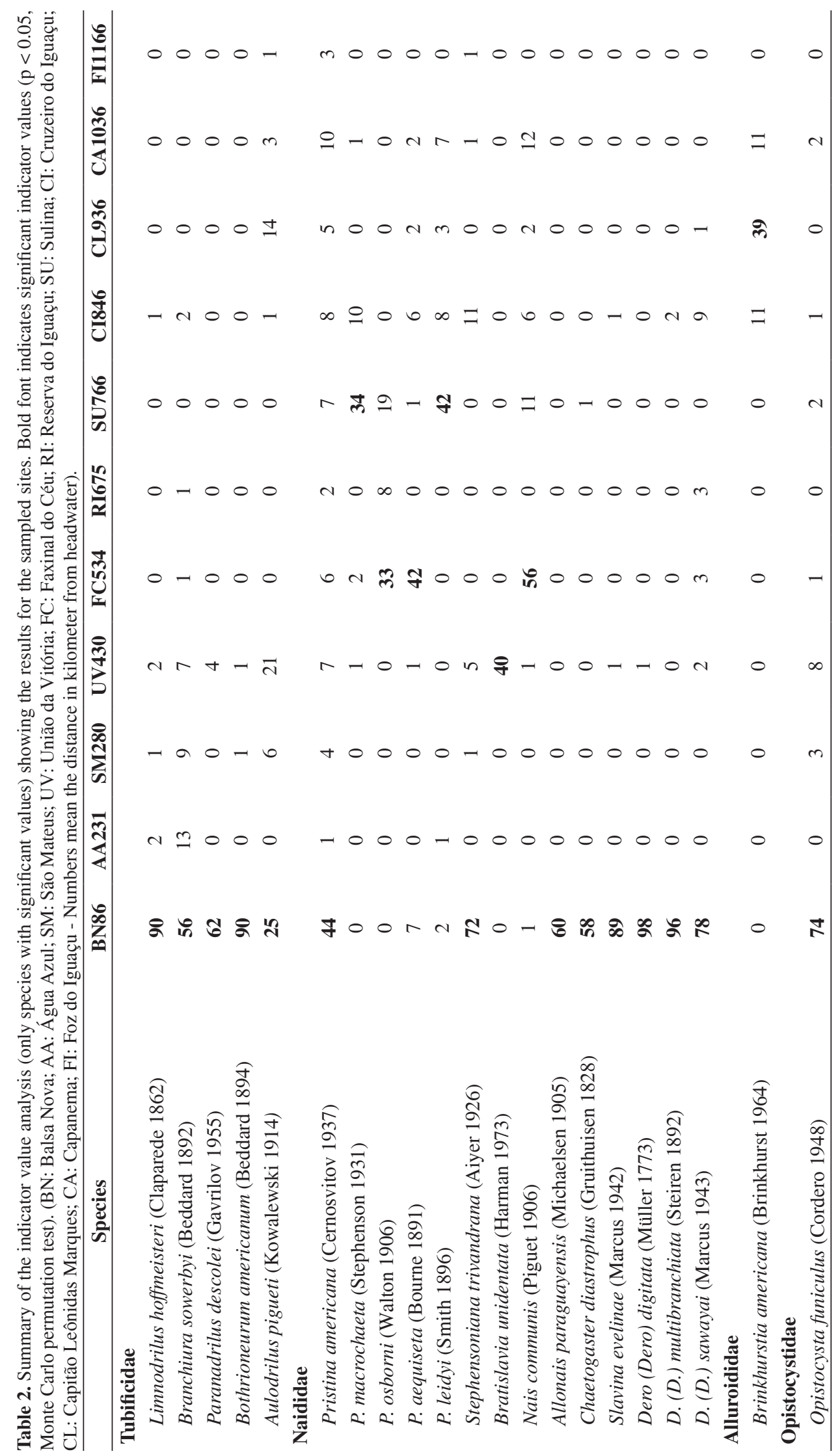


communities (Bohonak and Jenkins, 2003). Therefore, species with low dispersal tend to be different along great gradients (Palmer et al., 1996). Groups with low dispersal ability, such as Oligochaeta, are generally influenced by the composition of neighboring sites. Local colonization of this group is related to its ability to reproduce asexually (Smith, 1986), and producing cocoons buried in sediment (Lazim et al., 1989) that can tolerate adversity imposed by catastrophic events (for example, flood and drought). Thus, dispersal may act as a structuring force, leading to a constant flow of propagules; then closely connected sites harbor more similar assemblages than sites further apart (Cottenie et al., 2003). These aspects also support our findings, once assemblages of the First, Second, and Third Plateaus were similar within a plateau, rather than between plateaus. In addition, dispersion may be disrupted in the portion of the Iguaçu river, where the cascade of reservoirs are located, leading to decreased species richness in the lower stretches of the river.

The presence and abundance of organisms at a site depends on action of environmental filters, including both historical and ecological constraints ranging from landscape to micro-habitat scales (Poff 1997; Bonada et al. 2005). Many studies have sought to identify the patterns of macroinvertebrate distribution in both large geographical areas (Heino et al. 2002) and small ones (Adámek et al. 2010), showing a strong relationship between aquatic biota and environmental variables (Bonada et al. 2005). To understand these influences on the composition of Oligochaeta assemblages in the Iguaçu River, we performed a canonical correspondence analysis (CCA). Most important variables were altitude and some environmental factors (conductivity, substrate type and temperature). Although the distribution of Oligochaeta is affected by a number of variables interacting mutually, this group is directly related to substrate type (Verdonschot, 2001; Bletter et al., 2008) and hydromorphological characteristics (Takeda et al., 2001; Bletter et al., 2008). The ability of Oligochaeta to grow and develop in lotic environments is a result of a series of complex interactions between hydrology, water quality and biotic factors (Verdonschot, 2001).

Most physical and chemical factors are defined by geology, geomorphology and climate, but aquatic ecosystems can also be affected by human activities. The river regulation resulting from a cascade of reservoirs can cause intense physical, chemical and biological changes (Barbosa et al., 1999; Nogueira et al., 2002). In this study, higher values of conductivity and related variables, such as nutrients and suspended material, were recorded in the stretch near the headwater (First Plateau; not dammed). Lower values were recorded in the Third Plateau (far from the river headwater; in the First reservoir of the cascade). This can be explained by the Cascading Reservoir Continuum Concept (Barbosa et al., 1999), which supports that in rivers with reservoirs in series, these variables are higher in upper stretches ("inverted gradient"), counteracting the River Continuum Concept (Vannote et al., 1980) in which the highest concentrations of nutrients and organic matter are in lower stretches. Schenková and Helesic (2006) observed that the composition of Oligochaeta assemblage reflects the condition and change of human activity, and this was verified in this study by the outstanding changes in assemblage along the Iguaçu River, from its stretch with low water quality in the First Plateau to the reservoir cascade in the Third Plateau.

The change in composition of Oligochaeta assemblage along the Iguaçu River was characterized by the high abundance of taxa tolerant to low water quality in the First Plateau, such as L. hoffmeisteri, B. sowerbyi, B. americanum, D. (D.) digitata, D. (D.) multibranchiata and D. (A.) costatus, which feeds on particulate organic matter. Some aquatic Oligochaeta species are abundant in organically polluted water because of a lack of competition for food and space, which is also linked to tolerance to reduced oxygen conditions (Brinkhurst et al., 1983). Species of Tubificidae (Brinkhurst and Gelder, 1991) and species of Dero (Martin, 1996) are good indicators of environmental conditions related to organic pollution and low levels of oxygen concentration of lakes and rivers. These species were abundant in the First Plateau, decreasing their abundances along the Iguaçu River, especially in stretches below dams. Dumnicka (1996) observed that the first Oligochaeta to be eliminated below reservoirs were Tubificidae, probably because water from reservoirs present high erosive capacity, removing fine particulate organic and inorganic matter, leading to a reduction in suitable habitats for this group.

In the Second and Third Plateaus, few species were dominant, with an increase in the occurrence of Naididae below dams. According to Dumnicka (1987), Naididae comprises a considerable part of the bottom fauna below reservoirs. This is related to: i) the high primary productivity of phytoplankton recorded in the Iguaçu river (below dams), due to advection from reservoirs (Train et al. 2005), because this family is known to feed mainly on these organisms (Brinkhurst and Gelder, 1991); and ii) their plasticity, allowing them to cope with the disturbances caused by dams (Voshell and Simons, 1984), because species of this family usually possess high reproductive rates and develop quickly (Soster and McCall 1990).

The results of this study demonstrate a clear decrease in species richness along the Iguaçu River, chiefly due to the reduction of Tubificidae. In addition, it shows that the Iguaçu River is a complex river in which the Oligochaeta assemblage is related to environmental characteristics, but it was difficult to distinguish clearly between the effects of natural factors and anthropogenic disturbances. However, it was clear that the species richness and composition of the Oligochaeta assemblage of the Iguaçu River is explained by a strong environmental gradient. It is primarily influenced by altitude, and by some environmental variables such as conductivity, substrate type and temperature, exacerbated by anthropogenic activities (human occupation and damming). Usually, monitoring programs of freshwater ecosystems have used surrogate taxonomic groups, assuming that the results can be extrapolated to other unstudied groups. Our findings supported the use of Oligochaeta as surrogate taxa 
to predict environmental change along impacted (dammed and eutrophic) rivers. The validity of this was indicated by the strong and significant gradient registered, from the headwater to the mouth of the Iguaçu River.

Acknowledgements - The authors are grateful to the 'Núcleo de Pesquisas em Limnologia, Ictiologia e Aquicultura' (Nupélia); for the financial support of the CT-HIDRO/CNPq (Proc. 50.6775/2004-5) project, organized by professor Flavio da Costa Fernandes; to CNPq and CAPES for a scholarship granted to the first author; and to the Chemistry Laboratory of Universidade Estadual de Maringá for providing water quality data. Luiz Carlos Gomes was also supported by CNPq (Bolsa Produtividade).

\section{References}

ADÁMEK, Z., ORENDT, C., WOLFRAM, G. and SYCHRA, J., 2010. Macrozoobenthos response to environmental degradation in a heavily modified stream: Case study the Upper Elbe River, Czech Republic. Biologia, vol. 65, no. 3, p. 527-536. http://dx.doi. org/10.2478/s11756-010-0043-5

BARBOSA, FAR., PADISÁK, J., ESPÍNDOLA, ELG., BORICS, G. and ROCHA, O., 1999. The Cascading Reservoir Continuum Concept (CRCC) and its application to the river Tietê-Basin, São Paulo State, Brazil. In TUNDISI, JG. and STRASKRABA, M. Theoretical Reservoir Ecology and its Applications. São Carlos: Brazilian Academy of Sciences and Backhuys Publishers. p. 425-437.

BEHREND, RDL., FERNANDES, SEP., FUJITA, DS. and TAKEDA, AM., 2009. Eight years of monitoring aquatic Oligochaeta from the Baia and Ivinhema Rivers. Brazilian Journal of Biology, vol. 69, no. 2, p. 559-571. http://dx.doi.org/10.1590/ S1519-69842009000300011

BLETTER, M., AMSLER, M., EZCURRA DE DRAGO, I. and MARCHESE, M., 2008. Effects of stream hydraulics and other environmental variables on density of Narapa bonettoi (Oligochaeta) in the Paraná River system. River Research and Applications, vol. 24, p. 1124-1140.

BOHONAK, AJ. and JENKINS, DG., 2003. Ecological and evolutionary significance of dispersal by freshwater invertebrates. Ecology Letters, vol. 6, p. 783-796. http://dx.doi.org/10.1046/j.14610248.2003.00486.x

BONADA, N., ZAMORA-MUÑOZ, C., RIERADEVALL, M. and PRAT N., 2005. Ecological and historical filters constraining spatial caddisfly distribution in Mediterranean rivers. Freshwater Biology, vol. 50, p. 781-797. http://dx.doi.org/10.1111/j.13652427.2005.01357.x

BRINKHURST, RO., CHAPMAN, PM. and FARRELL, MJ., 1983. A comparative study of respiration rates of some aquatic oligochaetes in relation to sublethal stress. Internationale Revue der Gesamten Hydrobiologie, vol. 2, p. 1-89.

BRINKHURST, RO. and GELDER, SR., 1991. Annelida: Oligochaeta and Branchiobdellida. In THORP, JH. and COVICH, AP. Ecology and Classification of North American Freshwater Invertebrates. San Diego: Academic Press. p. 401-433.

BRINKHURST, RO. and MARCHESE, MR., 1991. Guia para la identificacion de oligoquetos aquáticos continentales de Sud y Centro America. Santo Tomé: Asociación de Ciencias Naturales del Litoral. 207 p.
BROSSE, S., ARBUCKLE, CJ. and TOWSEND, CR., 2003. Habitat scale and biodiversity: influence of catchment, stream reach and bedform scales on local invertebrate diversity. Biodiversity and Conservation, vol. 12, p. 2057-2075. http:// dx.doi.org/10.1023/A:1024107915183

BUNN, SE. and ARTHINGTON, AH., 2002. Basic principles and ecological consequences of altered flow regimes for aquatic biodiversity. Environmental Management, vol. 30, p. 492-507. http://dx.doi.org/10.1007/s00267-002-2737-0

CALLISTO, M., GOULART, M., BARBOSA, FAR. and ROCHA, O., 2005. Biodiversity assessment of benthic macroinvertebrates along a reservoir cascade in the lower São Francisco River (Northeastern Brazil). Brazilian Journal of Biology, vol. 65, no. 2, p. 229-240. http://dx.doi.org/10.1590/S1519-69842005000200006

COLLADO, R., KASPRZAK, P. and SCHMELZ, RM., 1999. Oligochaeta and Aphanoneura in two Northern German hardwater lakes of different trophic state. Hydrobiologia, vol. 406, p. 143-148. http://dx.doi.org/10.1023/A:1003700604272

COLLADO, R. and SCHMEL, RM., 2001. Oligochaete distribution patterns in two german hardwater lakes of different trophic state. Limnologica, vol. 31, p. 317-328. http://dx.doi.org/10.1016/ S0075-9511(01)80036-0

CORTES, RMV., FERREIRA, MT., OLIVEIRA, SV. and OLIVEIRA, D., 2002. Macroinvertebrate community structure in a regulated river segment with different flow conditions. River Research and Applications, vol. 18, p. 367-382. http://dx.doi. org/10.1002/rra.679

COTTENIE, K., 2005. Integrating environmental and spatial processes in ecological community dynamics. Ecology Letters, vol. 8, p. 1175-1182. PMid:21352441. http://dx.doi.org/10.1111/ j.1461-0248.2005.00820.x

COTTENIE, K., MICHELS, E., NUYTTEN, N. and DE MEESTER, L., 2003. Zooplankton metacommunity structure: regional vs. local processes in highly interconnected ponds. Ecology, vol. 84, p. 9911000. http://dx.doi.org/10.1890/0012-9658(2003)084[0991:ZM SRVL]2.0.CO;2

DARRIGRAN, GS., MARTÍN, M., GULLO, B. and ARMENDÁRIZ, L., 1998. Macroinvertebrates associated with Limnoperna fortunei (Dunker, 1857) (Bivalvia, Mytilidae) in Río de la Plata, Argentina. Hydrobiologia, vol. 367, p. 223-230. http://dx.doi. org/10.1023/A:1003244603854

DIACONU, AV. and RISNOVEANU, G., 1993. Changes of the structure and functioning of the benthic oligochaete communities from the Danube delta aquatic ecosystems (1976-1982). Revue Roumanie de Biologie, vol. 2, p. 171-179.

DUFRÊNE M. and LEGENDRE P., 1997. Species assemblages and indicator species: the need for a flexible asymmetrical approach. Ecological Monographs vol. 67, p. 345-366. http:// dx.doi.org/10.1890/0012-9615(1997)067[0345:SAAIST]2.0.CO;2

DUMNICKA, E., 1987. The effect of dam reservoirs on oligochaete communities in the River Dunajec (Southern Poland). Acta Hydrobiologica, vol. 29, p. 25-34.

-, 1996. Upstream-downstream movement of macrofauna (with special reference to Oligochaetes) in the River Raba below a reservoir. Hydrobiologia, vol. 334, p. 193-198. http://dx.doi. org/10.1007/BF00017369

GOTELLI, NJ. and COLWELL, RK., 2001. Quantifying biodiversity: procedures and pitfalls in the measurement and comparison of 
species richness. Ecology Letters, vol. 4, p. 379-391. http://dx.doi. org/10.1046/j.1461-0248.2001.00230.x

HANSEN, EA. and CLOSS, GP., 2007. Temporal consistency in the long-term spatial distribution of macroinvertebrate drift along a stream reach. Hydrobiologia, vol. 575, p. 361-371. http://dx.doi. org/10.1007/s10750-006-0384-9

HEINO, J., MOUTKA, T. and PAAVOLA, R., 2003. Determinants of macroinvertebrate diversity in headwater streams: regional and local influences. Journal of Animal Ecology, vol. 72, p. 425-434. http://dx.doi.org/10.1046/j.1365-2656.2003.00711.x

HEINO, J., MUOTKA, T., PAAVOLA, R., HÄMÄLÄINEN, H. and KOSKENNIEMI, E., 2002. Correspondence between regional delineations and spatial patterns in macroinvertebrate assemblages of boreal headwater streams. Journal of the North American Benthological Society, vol. 21, no. 3, p. 397-413. http:// dx.doi.org/10.2307/1468478

HEINO, J., MYKRA, H., KOTANEN, J. and MUOTKA, T., 2007. Ecological filters and variability in stream macroinvertebrate communities: do taxonomic and functional structure follow the same path? Ecography, vol. 30, p. 217-230.

JACOBSEN, D., SCHULTZ, R. and ENCALADA, A., 1997. Structure and diversity of stream macroinvertebrate assemblages: the influence of temperature with altitude and latitude. Freshwater Biology, vol. 38, p. 247-261. http://dx.doi.org/10.1046/j.13652427.1997.00210.x

JORCIN, A. and NOGUEIRA, MG., 2008. Benthic macroinvertebrates in the Paranapanema reservoir cascade (southeast Brazil). Brazilian Journal of Biology, vol. 68, no. 4, p. 1013-1024. http://dx.doi. org/10.1590/S1519-69842008000500009

JULIO JUNIOR, HF., BONECKER, CC. and AGOSTINHO, AA., 1997. Reservatório de Segredo e sua inserção na bacia do Iguaçu. In AGOSTINHO, AA. and GOMES, LC. Reservatório de Segredo: bases ecológicas para o manejo. Maringá: EDUEM. p. 1-17.

LAZIM, MN., LEARNER, MA. and COOPER, S., 1989. The importance of worm identity and life history in determining the vertical distribution of tubificids (Oligochaeta) in a riverine mud. Hydrobiologia, vol. 178, p. 81-92. http://dx.doi.org/10.1007/ BF00006115

MAACK, R., 2002. Geografia física do Estado do Paraná. Curitiba: Imprensa Oficial. 440 p.

McALLISTER, DE., CRAIG, JF., DAVIDSON, N., DELANY, S. and SEDDON, M., 2000. Biodiversity impacts of large dams. A contributing paper to the World Commission on Dams. Available from: <http://www.damsreport.org/docs/kbase/contrib/env245.pdf >.

MARCHESE, MR., WANTZEN, KM. and DRAGO, IE., 2005. Benthic invertebrate assemblages and species diversity patterns of the upper Paraguay River. River Research and Applications, vol. 21, p. 485-499. http://dx.doi.org/10.1002/rra.814

MARTIN, P., 1996. Oligochaeta and Aphanoneura in ancient lakes: a review. Hydrobiologia, vol. 334, p. 63-72. http://dx.doi. org/10.1007/BF00017354

MERENDA, EA., 2004. Caracterização ambiental da bacia do Rio Iguaçu e a da área de entorno do reservatório de Segredo. Maringá: Universidade Estadual de Maringá. 70 p. Dissertação de Mestrado em Geografia.

NIJBOER, RC., WETZEL, MJ. and VERDONSCHOT PFM., 2004. Diversity and distribution of Tubificidae, Naididae and Lumbriculidae
(Annelida: Oligochaeta) in the Netherlands: an evaluation of twenty years of monitoring data. Hydrobiologia vol. 520, p. 127141. http://dx.doi.org/10.1023/B:HYDR.0000027732.88238.61

NOGUEIRA, MG., JORCIN, A., VIANNA, NC. and BRITTO, Y., 2002. Uma avaliação dos processos de eutrofização nos reservatórios em cascata do rio Paranapanema (SP/PR), Brasil. In CIRELLI, AF. and CHALAR, GM. El água en iberoamérica: De la limnologia a la gestión en Sudamérica. Buenos Aires: CYTED XVII-CETA. p. 91-106.

PALMER, MA., ALLAN, JD. and BUTMAN, CA., 1996. Dispersal as a regional process affecting the local dynamics of marine and stream benthic invertebrates. Trends in Ecology and Evolution, vol. 11, p. 322-326. http://dx.doi.org/10.1016/01695347(96)10038-0

PARDO, I., CAMPBELL, IC. and BRITTAIN, JE., 1998. Influence of dam operation on mayfly assemblage structure and life histories in two south-eastern Australian streams. Regulated Rivers: Research and Management, vol. 14, p. 285-295. http:// dx.doi.org/10.1002/(SICI)1099-1646(199805/06)14:3<285::AIDRRR502>3.0.CO;2-6

PASTERIS, A., BONACINA, C. and BONOMI, G. 1994. Observations on cohorts of Tubifex tubifex cultured at different food levels, using cellulose substrate. Hydrobiologia, vol. 278, p. 315-320. http://dx.doi.org/10.1007/BF00142341

PETTS, GE., 1984. Impounded Rivers: Perspectives for Ecological Management. Chichester: Wiley. 326 p.

PETTS, GE. and GREENWOOD, M., 1985. Channel changes and invertebrate faunas below Nant-y-Môch dam, river Rheidol, Wales UK. Hydrobiologia, vol. 122, p. 65-80. http://dx.doi. org/10.1007/BF00018961

POFF, NL., 1997. Landscape filters and species traits: towards mechanistic understanding and prediction in stream ecology. Journal of the North American Benthological Society, vol. 16, p. 391-409. http://dx.doi.org/10.2307/1468026

ROSENBERG, DM., McCULLY, P. and PRINGLE, CM., 2000. Global-scale environmental effects of hydrological alterations: introduction. Bioscience, vol. 50, no. 9, p. 746-751. http://dx.doi. org/10.1641/0006-3568(2000)050[0746:GSEEOH]2.0.CO;2

ROSIN, GC., OLIVEIRA-MANGAROTTI, DP., TAKEDA, AM. and BUTAKKA, CMM., 2009. Consequences of dam construction upstream of the Upper Paraná River floodplain (Brazil): a temporal analysis of the Chironomidae community over an eight-year period. Brazilian Journal of Biology, vol. 69, no. 2, p. 591-608. http://dx.doi.org/10.1590/S1519-69842009000300014

SCHENKOVÁ, J. and HELESIC, J., 2006. Habitat preferences of aquatic Oligochaeta (Annelida) in the Rokytná River, Czech Republic - a small highland stream. Hydrobiologia, vol. 564, p. $117-126$.

SHURIN, JB., HAVEL, JE., LEIBOLD, MA. and PINEL-ALLOUL, B., 2000. Local and regional zooplankton species richness: a scale independent test for saturation. Ecology, vol. 81, p. 30623073. http://dx.doi.org/10.1890/0012-9658(2000)081[3062:LA RZSR]2.0.CO;2

SMITH, ME., 1986. The ecology of Naididae (Oligochaeta) from an alkaline bog stream: life history, patterns and community structure. Hydrobiologia, vol. 133, p. 79-90. 
SODRÉ, FF. and GRASSI, MT., 2006. Changes in copper speciation and geochemical fate in freshwaters following sewage discharges. Water, Air, and Soil Pollution, vol. 178, p. 103-112.

SOSTER, FM. and McCALL, PL., 1990. Benthos response to disturbance in western Lake Erie: field experiments. Canadian Journal of Fisheries and Aquatic Science, vol. 47, p. 1970-1985. http://dx.doi.org/10.1139/f90-222

SURIANI, AL., FRANÇA, RS., PAMPLIN, PAZ., MARCHESE, M., LUCCA, JV. and ROCHA, O., 2007. Species richness and distribution of oligochaetes in six reservoirs on Middle and Low Tietê River (SP, Brazil). Acta Limnologica Brasiliensia, vol. 19, no. 4 , p. $415-426$.

TAKEDA, A.M., STEVAUX, J.C. and FUJITA, D.S., 2001. Effect of hydraulics, bed load grain size and water factors on habitat e abundance of Narapa bonnetoi Righi and Varela, 1983 of the Upper Parana River, Brazil. Hydrobiologia, vol. 463, p. 241-248. http://dx.doi.org/10.1023/A:1013180430540

THIENEMANN, A., 1954. Ein drittes biozonotisches Grundprinzip. Archiv für Hydrobiologie, vol. 49, p. 421-422.

TRAIN, S., JATI, S., RODRIGUES, LC. and PIVATO, BM., 2005. Distribuição espacial e temporal do fitoplâncton em três reservatórios da bacia do Rio Paraná. In RODRIGUEZ, L., THOMAZ, SM., AGOSTINHO, AA. and GOMES, LC. Biocenoses em reservatórios: Padrões espaciais e temporais. São Carlos: Rima. p. 73-86.
VANNOTE, RL., MINSHALL, GW., CUMMINS, KW., SEDELL, JR. and CUSHING, CE., 1980. The river continuum concept. Canadian Journal of Fisheries and Aquatic Science, vol. 37, p. 130-137. http://dx.doi.org/10.1139/f80-017

VERDONSCHOT, PFM., 2001. Hydrology and substrates: determinants of oligochaete distribution in lowland streams (The Netherlands). Hydrobiologia, vol. 463, p. 249-262. PMid:15012391. http://dx.doi.org/10.1023/A:1013132514610

VINSON, MR. and HAWKINS, CP., 1998. Biodiversity of stream insects: Variation at Local, Basin, and Regional Scales. Annual Review of Entomology, vol. 43, p. 271-293. http://dx.doi. org/10.1146/annurev.ento.43.1.271

VOSHELL, JR. and SIMMONS, GM., 1984. Colonization and succession of benthic macroinvertebrates in a new reservoir. Hydrobiologia, vol. 112, p. 27-39. http://dx.doi.org/10.1007/ BF00007663

WARD, JV. and STANFORD, JA., 1983. The serial discontinuity concept of lotic ecosystems. In FONTAINE, TD. and BARTELL, SM. Dynamics of Lotic Systems. Ann Arbor Publisher. p. 29-42.

-, 1995 The serial discontinuity concept: extending the model to floodplain rivers. Regulated Rivers: Research and Management, vol. 10, p. 159-168. http://dx.doi.org/10.1002/rrr.3450100211 